\title{
Sprawozdanie z III Ogólnopolskiej Sesji Naukowej pt. Życie prywatne Polaków w XIX wieku. „Świat dziecka”, Łódź, 8-9 października 2015 r.
}

Trzecia z kolei sesja naukowa dotycząca Życia prywatnego Polaków w XIX Łódzkiego oraz Instytut Historii i Stosunków Międzynarodowych Uniwersytetu Warmińsko-Mazurskiego w Olsztynie. Dwie pierwsze sesje miały miejsce w Olsztynie, obrady ostatniej natomiast odbyły się w gmachu IH UŁ przy ulicy Kamińskiego 27A w Łodzi.

W skromne progi IH UŁ przybyło wielu znanych badaczy i badaczek, którzy swoimi wystąpieniami uświetnili to wyjątkowe wydarzenie, wnosząc nowy wkład w polską historiografię. Sesja naukowa rozpoczęła się od przywitania gości przez organizatorów. Przemówienia wstępne wraz z powitaniem przybyłych uczestników i uczestniczek konferencji wygłosili prof. nadzw. dr hab. Jarosław Kita, reprezentujący Uniwersytet Łódzki, oraz dr Maria Korybut-Marciniak z Uniwersytetu Warmińsko-Mazurskiego. Po otwarciu sesji i przywitaniu prelegentów rozpoczęły się obrady.

Pierwszy panel został zatytułowany Dzieci z różnych warstw społecznych i z różnych środowisk. Jako pierwszy wystąpił prof. dr hab. Tadeusz Stegner z Uniwersytetu Gdańskiego, prezentując referat pt: Dziecko w rodzinie protestanckiej w Królestwie Polskim w XIX wieku. Prof. T. Stegner podkreślał, iż rodzina kształtująca młodego człowieka odgrywała niezwykle ważną rolę w XIX-wiecznym społeczeństwie. Utrzymujący się patriarchalny model rodziny wpływał na stosunki w jej wnętrzu i stawiał na piedestale mężczyznę. W związku z tym widoczne były znaczne różnice w wychowaniu dziewczynek i chłopców, podobnie zresztą jak w rodzinach katolickich. Jedyne co wyróżniało rodziny protestanckie była konfirmacja, dzięki której przedstawiciele młodzieży stawali się pełnoprawnymi członkami zboru.

Kolejny prelegent dr hab. Krzysztof Woźniak z Uniwersytetu Łódzkiego wraz z Konradem Woźniakiem z Humboldt-Universität zu Berlin, zaprezentowali interesujący referat pt: Folklor dziecięcy $w$ środowiskach niemieckich Królestwa Polskiego. Dziecko potraktowane zostało jako twórca, a źródłami do analizy lingwistycznej i historycznej były rymowanki pochodzące głównie z niemieckich środowisk wiejskich Królestwa Polskiego. Autorzy referatu zwrócili uwagę na trudność w przełożeniu ich na język polski, tak by zachować odpowiedni rym i rytm. Warto zwrócić uwagę na fakt, iż wszystkie rymowanki towarzyszyły dzieciom w zabawie. Autorzy referatu wyszczególnili kilka rodzajów rymowanek: o charakterze wychowawczym, pasterskie, żartobliwe, prześmiewcze, skatologiczne, naśladujące głosy przyrody, wyliczanki, naśladownictwo głosu ptaków, zwierząt. Niektóre odnosiły się w szyderczy sposób do polskich i żydowskich sąsiadów. 
Jako trzeci wystąpił profesor Uniwersytetu Łódzkiego dr hab. Jarosław Kita, prezentując artykuł pt: Peregrynacje dzieci do dziewiętnastowiecznych kurortów. Profesor podkreślił, iż do uzdrowisk na Zachodzie Europy wyjeżdżały tylko dzieci z elit społeczno-majątkowych - bogatej inteligencji, burżuazji, ziemiaństwa i arystokracji. Towarzyszyły najczęściej swoim rodzicom. Z drugiej strony zauważyć dawały się działania społeczników, którzy pomagali i finansowali wyjazdy dla dzieci niezamożnych. W drugiej połowie XIX w. coraz większą rolę pełnić zaczynały kurorty nadmorskie, gdzie dzieci miały dużo miejsc do zabawy. Nie wszystkie dzieci dobrze wspominały picie uzdrowiskowych wód, czy kąpiele w bardzo zimnej wodzie dla zahartowania organizmu czy owijanie w mokre prześcieradła. Dzieci miały także wpływ na inwestycje w sanatoriach, o czym traktowała druga część referatu. W trzeciej natomiast prof. J. Kita omawiał wyjazdy dzieci z „niezamożnych" rodzin.

Po trzech referatach wnoszących nowe spojrzenie na dziecko i jego rolę w rodzinie, nastąpiła przerwa kawowa, która pozwoliła na wymianę poglądów w kuluarach. Jako pierwsza po krótkiej przerwie wystąpiła współorganizatorka konferencji dr Maria Korybut-Marciniak z Uniwersytetu Warmińsko-Mazurskiego w Olsztynie z referatem zatytułowanym Dziecko w rodzinie urzędniczej w świetle materiałów Artura Dolińskiego. Autorka zaprezentowała postać Artura Dolińskiego - urzędnika wileńskiego - oraz jego rodzinę. W szczegółowy i dogłębny sposób doktor M. Korybut-Marciniak omówiła stosunek do córek, przygotowany dla nich osobiście przez Dolińskiego program nauczania w duchu narodowym i katolickim, obejmującym bardzo wiele dziedzin m. in. arytmetykę, fizykę, mineraologię, naukę języków obcych, historię i wiele innych, po zajęcia praktyczne typu kapelusznictwo czy rysunek. Doliński szczególnie dbał o córki i nie szczędził pieniędzy na toalety dla nich. Jednakże, jak podkreśliła prelegentka, badania pokazują, iż nie każdy urzędnik mógł sobie na to pozwolić, abstrahując od tego, iż nie każdy decydował się ze względów finansowych na założenie rodziny. Niektórych przewyższało sfinansowanie edukacji swoich dzieci. W rodzinach urzędniczych ojciec często był poza domem i wychowywał pociechy poprzez listy, zachowując przy tym zasady obowiązujące w rodzinach ziemiańskich.

Kolejna prelegentka wystąpiła z tematem Trudne dzieciństwo. O losach dzieci w Łodzi przełomu wieku XIX i XX. Dr Marzena Iwańska z Uniwersytetu Łódzkiego rozpoczęła swój referat od psychologicznego ukazania problemu trudnego dzieciństwa. Analiza psychologiczna pozwoliła na pogłębione przeniknięcie do świata dzieci z Łodzi, których dzieciństwo Autorka uznała za ciężkie, spędzone często w warunkach urągających człowieczeństwu. Dzieci w Łodzi na co dzień stykały się z problemem głodu, biedy, czy porzucenia. Ważkim zagadnieniem było również dzieciobójstwo. Gorzkie doświadczenia dzieciństwa wpływały niekorzystnie na rozwój emocjonalny i osobowy dzieci łódzkich. 
Kolejny referat także traktujący o dzieciach w Łodzi zaprezentowała mgr Sylwana Borszyńska z Uniwersytetu Łódzkiego. Wystąpienie zostało zatytułowane Życie dziecka w wielkoprzemystowej Łodzi w latach 1905-1914. Autorka wykorzystała w badaniach prasę łódzką oraz pamiętnik Heleny Anny Geyer. Mgr S. Borszyńska ukazała trudne warunki sanitarno-mieszkaniowe, przenalizowała kwestię wysokiej umieralności niemowląt w Łodzi oraz pomysły zapobiegania tej tragicznej sytuacji w postaci działalności prowadzonej przez Kroplę Mleka. Autorka zaprezentowała zagrożenia, jakie czyhały na dzieci w Łodzi - począwszy od przejechania przez wóz po wypadnięcie z okna, czy poparzenie ciała, po dzieciobójstwo i doznawanie przemocy fizycznej i psychicznej, jak i wykorzystywania pociech w celach zarobkowych. Mgr S. Borszyńska zwróciła uwagę na różnicę między dzieciństwem spędzonym w rodzinach ubogich a losem dzieci z rodzin zamożnych. Ważnym elementem było także ukazanie pozytywów, czyli kolonii letnich organizowanych dla dzieci z rodzin robotniczych, zabaw zimowych i przekazywania dla nich darów z okazji Świąt Bożego Narodzenia.

Po trzech referatach uczestnicy konferencji przystąpili do dyskusji, która zamykała pierwszy panel w tej części sesji naukowej. Głos w dyskusji zabrali prof. Tadeusz Stegner, dr Maria Korybut-Marciniak, dr hab. Krzysztof Woźniak, prof. Jarosław Kita, dr Antoni Maziarz, dr Marzena Iwańska oraz prof. Marta Sikorska-Kowalska. Dyskusja oscylowała wokół roli ojca w rodzinie i stosunku dzieci wobec niego, sposobach przeżywania śmierci dzieci w XIX w., pojęcia traumy, traktowania kobiet $\mathrm{z}$ nieślubnymi dziećmi w środowiskach protestanckich. Ze względu na dużą liczbę poruszonych wątków rozmowy przeniosły się w kuluary ze względu na przewidziany reżim czasowy. Uczestnicy kontynuowali dyskusję przy obiedzie serwowanym w Centrum Konferencyjnym przy ul. Kopcińskiego.

Druga część sesji zaczęła się o godzinie 15 referatem mgr Aleksandry Rybki z Uniwersytetu Łódzkiego zatytułowanym Kultura czytelnicza dziecka ziemiańskiego na przykładzie biblioteki pałacowej w Maluszynie. Autorka doszła do wniosku, iż dzieci ziemiańskie były zniechęcane dla beletrystyki, a kultura czytelnicza jako taka ściśle związana była z edukacją. Mimo stale wzrastającej liczby książek przeznaczonych stricte dla dzieci typu: bajki, legendy, rymowanki, kołysanki, dział dziecięcy w bibliotece ziemiańskiej nie zajmował dużo miejsca. Po przeczytaniu książki najważniejsza zdawała się późniejsza nad nią dyskusja oraz wymiana poglądów między dziećmi a dorosłymi czytelnikami.

Następny referat pt: Dziecko w chorobie. Opieka medyczna nad najmłodszymi w XIX wieku (na przykładzie cholery) wygłosiła dr Iwona Janicka z Uniwersytetu Gdańskiego. W pierwszej części swojego wystąpienia Autorka przedstawiła najważniejsze fakty dotyczące cholery, począwszy od jej przyczyn po objawy i przebieg. Ukazawszy warunki sanitarno-lokalowe, w jakich żyły dzieci, które zachorowały na cholerę, doktor Janicka przeszła do omówienia opieki jaką były 
one otaczane w trakcie choroby. Nie zawsze nawet pomimo odpowiedniej opieki ratowano dzieci od śmierci.

Kolejny referent prof. dr hab. Marek Przeniosło z Uniwersytetu Jana Kochanowskiego w Kielcach zaprezentował dwa referaty - swój i dr hab. prof. UJK Małgorzaty Przeniosło, która $\mathrm{z}$ ważnych względów nie mogła przybyć na sesję osobiście. Prof. M. Przeniosło wystąpił z referatem pt: Dziecko w rodzinie chłopskiej na terenie Królestwa Polskiego w latach I wojny światowej, dotykając tematu nieporuszanego $\mathrm{w}$ dotychczasowej historiografii polskiej. Pogorszenie sytuacji ekonomicznej na wsi było spowodowane działaniami wojennymi i rekwizycjami. Rodzina chłopska żyła w coraz gorszych warunkach, a żywienie rodziny odbywało się kosztem dzieci i osób starszych. W związku z tym, iż mężczyźni zostali wcieleni do armii, kobiety i młodzież musieli przejąć ich obowiązki. Dodatkowo na intensywne zmiany i sferę oddziaływania obyczajowego miały wpływ migracje ludności miejskiej na wieś w trakcie I wojny światowej. Dużym plusem był natomiast wysyp placówek szkolnych pod koniec wojny w latach 1917-1918. Wytworzone w warunkach wojennych stosunki wpłynęły na wzrost demoralizacji młodzieży, objawiającej się mniejszym szacunkiem do rodziców, stosowaniem używek, przygodnymi kontaktami seksualnymi z żołnierzami, czy szerzącym się bandytyzmie, w którym brały udział dzieci chłopskie. Okres I wojny światowej wpłynął na stopniowe odchodzenie od tradycyjnego modelu rodziny chłopskiej.

Referat dr hab. prof. UJK Małgorzaty Przeniosło nosił tytuł Wielka Kwesta Ogólnopolska „Ratujcie Dzieci” w latach 1916-1919 i traktował o działaniach Rady Głównej Opiekuńczej w trakcie I wojny światowej. W marcu 1916 r. RGO podjęła decyzję o zorganizowaniu Wielkiej Kwesty, z której zebrane fundusze trafiały do potrzebujących pomocy materialnej dzieci. Działania podzielono na 16 sekcji, dla przykładu były to m.in. sekcja zabaw, sekcja koncertów, sekcja teatrów, sekcja fotografii, sekcja zbierania datków od firm. Co ciekawe RGO zebrała 600 tysięcy rubli, z czego najwięcej zebrano (w biednej) Łodzi - aż 90 tysięcy rubli. Działania podejmowane 100 lat temu można porównać z dzisiaj funkcjonującą Wielką Orkiestrą Świątecznej Pomocy, która także zbiera datki na pomoc dla dzieci.

Następna prelegentka dr Joanna Sosnowska z Uniwersytetu Łódzkiego wygłosiła referat pt: Opieka nad dziećmi w działaniach Łódzkiego Chrześcijańskiego Towarzystwa Dobroczynności w latach 1889-1914. Dr Sosnowska jako pierwsza podczas sesji mówiła o funkcjonowaniu dziecka w instytucji. Powstałe w $1889 \mathrm{r}$. ŁChTD opiekowało się sierotami, chorymi oraz biednymi dziećmi z rodzin robotniczych, starcami i kalekami. W Łodzi funkcjonował szpital Anny Marii dla wszystkich dzieci bez względu na wyznanie. Co ważne Autorka dotarła do źródeł, które pokazywały, iż atmosfera w szpitalu była bardzo rodzinna i miła, a dzięki niej i odpowiedniej pielęgnacji dzieci szybko wracały do zdrowia. Zakładane ochronki pełniły rolę wychowawczą, ekonomiczną oraz opiekuńczą. Dodatkiem były także płatne przyfabryczne ogródki dziecięce, w których pracujący rodzice 
mogli zostawiać swoje pociechy. Funkcjonowała także szkoła rzemiosł, organizowano dzieciom kolonie letnie. Ze względu na dużą liczbę dzieci przed wyjazdem na kolonie dokonywano selekcji dzieci, dzieląc je na te, które potrzebowały wyjazdu na wieś w trybie pilnym, i na te, które posiadały rzeczywistą potrzebę wyjazdu, w końcu na te, których stan zdrowia nie wymagał wyjazdu. Ograniczało to liczbę dzieci, które korzystały z letnich kolonii. Działania ŁChTD wpływały na polepszenie trudnej sytuacji dzieci w Łodzi.

Po ostatnim referacie rozpoczęła się ożywiona dyskusja, w której głos zabrali: dr Hanna Kurowska, dr Antoni Maziarz, dr Iwona Janicka, prof. Tadeusz Stegner, dr Joanna Sosnowska, prof. Marek Przeniosło, prof. Jarosław Kita, dr Maria Korybut-Marciniak. Dyskutowano o cholerze wśród Żydów, o cholerze na Górnym Śląsku i Litwie, o wysyłaniu dzieci z miast (głównie z Łodzi i Warszawy) na wieś w trakcie I wojny światowej, warunkach przeżywania śmierci dziecka na wsi, chorobach, które w największym stopniu przyczyniały się do śmierci dzieci.

Po dyskusji, która objęła bardzo wiele wątków, uczestnicy konferencji mieli szansę posilić się przed następną częścią sesji na przerwie kawowej.

Jako pierwsza po przerwie wystąpiła dr Hanna Kurowska z Uniwersytetu Zielonogórskiego z referatem pt: Niemowle jako nowy obiekt zainteresowania rodziców, lekarzy i państwa. Autorka analizowała problem śmiertelności niemowląt, prezentując sposoby radzenia sobie z nim poprzez działalność lekarzy, higienistów oraz duchownych, działalność dobroczynną - zakładanie sierocińców i domów dla podrzutków, odejście państwa od karania kobiet rodzących nieślubne dzieci, wydawanie poradników dla matek szczegółowo omawiających co należało robić w trakcie trwania ciąży, w połogu i po nim, jak karmić potomstwo. Dr H. Kurowska zauważyła, iż większe zainteresowanie niemowlakami wpłynęło pozytywnie m.in. na spadek wskaźnika zgonów.

W następnym panelu Dziecko w literaturze jako pierwsza wystąpiła mgr Kinga Mielczarek z Akademii Pomorskiej w Słupsku. Zaprezentowała referat pt: „Biedne dziecko, przywykło od najpierwszych lat styszeć, że jest brzydka i kaleka". Bohaterowie dziecięcy w utworach Marii Sadowskiej. Mgr K. Mielczarek podkreśliła fakt, iż Sadowska w swojej twórczości portretowała dziecko o wiele wcześniej niż Eliza Orzeszkowa. Prezentowała najczęściej dzieci kalekie, upośledzone fizycznie, źle traktowane przez społeczeństwo, a nawet własnych rodziców. Bohaterowie dziecięcy Sadowskiej z Pamiętników muchy i Starej panny to ludzie o ponadprzeciętnych zdolnościach, których traktowała jako pełnoprawnych członków społeczeństwa, jednocześnie potępiając rodziców tych kalekich dzieci. Jako jedyna pisała o miłościach kalekich dzieci, co wyróżniało jej twórczość spośród innych dzieł.

Kolejny referat pt: „Już mu się tylko pacierz należy”. Literackie ujęcie choroby i śmierci dziecka na XIX-wiecznej polskiej wsi wygłosiła mgr Anna Kowalczyk z Uniwersytetu Warszawskiego. Autorka podjęła się analizy traktowania dzie- 
cięcych chorób w utworach literackich takich jak Tomek Baran, Sprawiedliwie i Anielka. W każdym przypadku znachorzy nie mieli pomysłu na leczenie dzieci, a ignorancja, ciemnota i bezrefleksyjność rodziców dodatkowo pogłębiała nieszczęścia. Mgr A. Kowalczyk doszła do wniosku, iż ukazane w literaturze ubóstwo i brak opieki lekarskiej, która na wieś nie docierała często powodowała śmierć dzieci zdanych tylko na siebie i los.

Po powyższym referacie rozpoczęła się ożywiona dyskusja, którą rozpoczął prof. Tadeusz Stegner od uwag do referatu mgr Kingi Mielczarek, która szczegółowo na nie odpowiedziała. Głos zabrał także prof. Jarosław Kita oraz mgr Marta Kłak-Ambrożkiewicz, dr Iwona Janicka, dr Hanna Kurowska, dr hab. Krzysztof Woźniak, dr Antoni Maziarz oraz dr Maria Korybut-Marciniak. Dyskusja dotyczyła nierealnego obrazu jaki dawała literatura, prezentująca wyobrażenia autorów o wsi, a nie rzeczywistość, o magicznych zabiegach i prawach jakimi rządziła się wieś w XIX wieku, o mamkach, które karmiły dzieci ziemiańskie.

Dyskusja przeniosła się w kuluary, bowiem kolejnym punktem sesji była uroczysta kolacja przygotowana dla uczestników i osób wspierających organizatorów w przygotowaniu i przebiegu konferencji. Kolacja odbyła się w Centrum Konferencyjnym przy ul. Kopcińskiego i służyła nawiązaniu kontaktów oraz bliższemu poznaniu się prelegentów. Organizatorzy powitali oficjalnie gości, wygłosili mowy oraz wznieśli uroczysty toast.

9 października rozpoczął się drugi dzień sesji naukowej. Pierwszy referat w panelu Portrety rodzinne wygłosiła dr hab. prof. UŁ Marta Sikorska-Kowalska pt: Narodziny socjalisty. Heryngowie $i$ ich dzieci. Prof. M. Sikorska-Kowalska postawiła tezę, iż relacje międzypokoleniowe w rodzinie Heryngów opierały się na konflikcie pokoleniowym. Głównym trzonem była ideologia. Autorka analizowała definicję pokolenia, rodziny oraz konfliktu międzypokoleniowego. Przyjrzała się relacji w małżeństwie Stefanii z Heryngów i Maksymiliana Horwitz-Waleckiego, którzy odcięli się od wartości wyniesionych z rodzinnych domów. W los trójki ich dzieci wpisane było tułactwo (każde z nich urodziło się w innym kraju), ciągłe aresztowania rodziców, wysyłane za nimi listy gończe, ucieczki, odwiedziny w więzieniu, opieka wujów i ciotek z partii lub mieszczaństwa. Ciągłe zmiany mieszkań wpływały na brak poczucia posiadania. Surowość Horwitza jako ojca wpłynęła na wychowanie potomstwa. Jedna z córek odcięła się w dorosłym życiu od polityki, wiodła światowe życie i kontestowała wartości rodziców, przeciwstawiając się żądaniom ojca. Autorka ukazała trudne losy dzieci działaczy socjalistycznych. Otwarte natomiast pozostało pytanie kim te dzieci się czuły - Polakami, Żydami czy Rosjanami?

Drugi referat wygłosiła mgr Agnieszka Weseli z Warszawy, która zaprezentowała temat Czyste przed Bogiem, niewinne dla narodu, zdrowe dla spoleczeństwa. Normatywne konstrukcje seksualności dziecięcej na ziemiach polskich $w$ kontekście społeczno-politycznym od 2. połowy XIX wieku do I wojny światowej. 
Autorka posłużyła się dziełami z medycyny sądowej i medycyny jako źródłami. Zwróciła uwagę na duże znaczenie Kościoła katolickiego w wychowaniu dzieci, który uznawał seks za zagrożenie moralności, a wychowanie dziecka w czystości za najważniejszą kwestię. Mgr A. Weseli odwołała się do scjentystycznej wizji świata i cytowała Spencera odnośnie popędów seksualnych. Podkreślała, iż poradniki uwypuklały aseksualność dzieci.

Trzeci prelegent zaprezentował referat pt: Dzieci Chłapowskich $w$ fotografii $i$ wspomnieniach, czemu towarzyszyła prezentacja multimedialna. Dr Emilian Prałat z Uniwersytetu Adama Mickiewicza w Poznaniu zaprezentował postać Dezyderego Chłapowskiego, który był wychowywany przez ojca. Francuski model wychowania zderzał się z pruskim, wywierana była duża presja na dzieci, ale także dawało się zauważyć ojcowską troskę. Autor zauważył, iż w II połowie XIX w. nastąpił wzrost liczby zdjęć robionych dzieciom, co świetnie pokazują materiały zachowane w archiwach Chłapowskich w Krakowie i Warszawie.

Kolejna prelegentka mgr Marta Kłak-Ambrożkiewicz z Muzeum Narodowego w Krakowie przedstawiła referat pt: Kraj lat dziecinnych. Matejkowie, ilustrując go prezentacją multimedialną. Autorka zaczęła od przybliżenia słuchaczom trudnych losów dzieciństwa Jana Matejki. Po utracie matki w wieku 7 lat, Jan był wychowywany przez surowego, zimnego i ciągle pracującego ojca oraz przez starsze rodzeństwo. Dzięki bratu znalazł się w Szkole Sztuk Pięknych w Krakowie i tak zaczęła się jego ścieżka kariery. Dalsza część referatu odnosiła się do poznania przyszłej małżonki Teodory i ich małżeństwa. Matejko jako ojciec zapewnił dzieciom wszystko, czego sam nie miał, zabawki, guwernerów, zwierzęta, wyjazdy do wód, a nawet daczę. Był troskliwym, czułym, uczestniczącym w życiu swoich czterech dzieci ojcem. W trakcie rozwoju choroby psychicznej żony, sam musiał wychowywać dzieci. Autorka referatu ukazała mało znane karykatury twórczości Matejki, ukazujące życie rodzinne. Mgr M. Kłak-Ambrożkiewicz skontrastowała ze sobą dwa różne modele wychowania i dwa różne dzieciństwa.

Po ostatnim referacie uczestnicy sesji mieli czas na dyskusję i wymianę poglądów. Głos zabrali: prof. Tadeusz Stegner, mgr Agnieszka Weseli, prof. Marta Sikorska-Kowalska, prof. Jarosław Kita, dr Maria Korybut-Marciniak, dr Emilian Prałat, dr Marzena Iwańska, mgr Marta Kłak-Ambrożkiewicz.

Po krótkiej przerwie kawowej rozpoczęła się ostatnia część sesji. Pierwszym referentem był mgr Piotr Bojarski z Uniwersytetu Warmińsko-Mazurskiego w Olsztynie, który zaprezentował temat Dzieciństwo $w$ dobie Wielkiej Wojny. Obraz życia dziecka na kartach pamiętnika Piotra Bojarskiego. Mgr P. Bojarski stworzył referat o swoim dziadku, który wspomnienia spisał w latach 80 . XX w. Dzieciństwo ukazane w wystąpieniu naznaczone było piętnem działań wojennych, obserwowaniem z bliska niemieckich i austriackich wojsk, koniecznością pomocy matce w gospodarstwie, głodem, chorobą oraz wyczekiwaniem na powrót ojca z wojny, z którym kontakty były bardzo chłodne. 
Kolejne wystąpienie zapoczątkowało nowy panel Wokót wychowania. Jako pierwszy wystąpił dr Antoni Maziarz z Uniwersytetu Opolskiego z referatem pt: Szkolnictwo poznańskich wspólnot zakonnych w XIX wieku. Dr Maziarz omówił kwestię długości nauki oraz jej kosztów, a także wymienił przedmioty, których nauczano w szkołach zakonnych. Siostry zakonne tworzyły uczniom rodzinną atmosferę, dzięki czemu zdobywały szacunek wychowanek, a nawet stawały się dla nich autorytetami. Profil szkół budził głęboką niechęć organów niemieckich, którym zależało na wykorzenieniu polskości. Szkoły zakonne były tworzone oddolnie, a siostry uczące $\mathrm{w}$ nich pochodziły z najznamienitszych rodów ziemiańskich.

Następnie mgr Monika Wąs z Uniwersytetu Pedagogicznego w Krakowie zaprezentowała referat pt: Dziecko oczami nauczyciela. Zapiski Mikołaja Rybowskiego jako przyczynek do badań dzieciństwa w XIX wieku. Mgr M. Wąs przybliżyła uczestnikom sesji postać Mikołaja Rybowskiego, który pełnił rolę guwernera hrabiego Andrzeja Potockiego. Dzięki dużej ilości czasu spędzanej wspólnie mężczyzna znał wady i zalety dziecka. Uczył go podczas spacerów, a także w domu. Wychowanie było regulowane ścisłymi zasadami panującymi w rodzinach ziemiańskich.

Po referacie zabrał głos prof. Jarosław Kita, który stwierdził, iż należało zmienić w tytule referatu słowo „nauczyciela" na „guwernera”.

Kolejny referat pt: Wychowanie dziecka $w$ XIX stuleciu $w$ świetle praktycznych porad Lucyny Ćwierczakiewiczowej zaprezentowały wspólnie mgr Grażyna Czerniak i mgr Justyna Zyśk z Uniwersytetu Warmińsko-Mazurskiego w Olsztynie. Autorki analizowały kalendarze pisane przez Lucynę Ćwierczakiewiczową. Przedstawiała ona w nich rozmaite porady odnoszące się do mycia dzieci, kołysania ich, kolorów zabawek kupowanych dla pociech, o diecie dzieci, stroju, higienie. Kobieta wspierała się autorytetami nauki i tworzyła zbiory zasad dla młodych matek. Kształtowała tym samym trendy wychowawcze.

Ostatni referat w całej sesji wygłosiła mgr Daria Domarańczyk z Uniwersytetu Łódzkiego. Zaprezentowała temat Psychologia dziecka na lamach prasy Królestwa Polskiego i Galicji przełomu XIX i XX wieku. Wykorzystywała jako źródło prasę naukowo-kulturalną, jednakże, jak zauważyła mgr D. Domarańczyk, psychologia dzieci nie cieszyła się popularnością. Właściwie stanowiła jedynie margines zainteresowań psychologów w XIX w. Autorka wymieniła postacie, które jako pierwsze podejmowały tego typu tematykę i byli to m. in. Julian Ochorowicz, Aniela Szycówna.

Po wystąpieniach prelegentów był czas na kolejną ożywioną dyskusję na temat zaprezentowanych tekstów. Głos zabrali: dr Marzena Iwańska, dr Joanna Sosnowska, dr Antoni Maziarz, dr Maria Korybut-Marciniak, mgr Piotr Bojarski, mgr Marta Kłak-Ambrożkiewicz, prof. Jarosław Kita oraz prof. Marta Sikorska-Kowalska, która miała uwagę do referatów mgr Moniki Wąs, mgr Piotra 
Bojarskiego, mgr Grażyny Czerniak i mgr Justyny Zyśk wskazującą na konieczność przeprowadzenia konfrontacji z innymi źródłami historycznymi, wyciągnięcia wniosków oraz zmiany wprowadzenia innej konstrukcji referatów.

Na podsumowanie dwóch dni owocnych obrad III sesji naukowej Życie Prywatne Polaków w XIX wieku ,Świat dziecka" głos zabrał organizator prof. Jarosław Kita. Stwierdziwszy, iż czarny obraz dzieciństwa, jaki uzyskaliśmy był efektem dostępnych źródeł, prof. J. Kita zaznaczył dodatkowo, że głównie eksponowane w trakcie wystąpień były dzieci ziemiańskie i inteligenckie. $Z$ tychże powodów sesja bynajmniej nie wyczerpała tematu dzieciństwa w XIX w. Po podziękowaniach, głos zabrała także organizatorka dr Maria Korybut-Marciniak, która podała wstępny tytuł kolejnej już czwartej sesji naukowej z cyklu Życie Prywatne Polaków w XIX wieku, który będzie brzmiał „Wokót mody” i odbędzie się w 2016 r. w Olsztynie.

III sesja naukowa zakończyła się wspólnym obiadem i toastem wzniesionym za pomyślność dalszej owocnej współpracy dwóch zaprzyjaźnionych ośrodków naukowych w Łodzi i w Olsztynie.

Sylwana Borszyńska

(Uniwersytet Łódzki, Wydział Filozoficzno-Historyczny)

http://dx.doi.org/10.18778/2080-8313.14.16

Sprawozdanie z konferencji naukowej pt. Miasto, masa i... projekt. Historyczne trajektorie dyskursów modernizacyjnych", Lódź, 4-5 grudnia 2015 r.

W'dniach 4-5 grudnia 2015 r. na Wydziale Ekonomiczno-Socjologicznym Uniwersytetu Łódzkiego odbyła się interdyscyplinarna konferencja naukowa pt. Miasto, masa i... projekt. Historyczne trajektorie dyskursów modernizacyjnych, zorganizowana przez niedawno utworzone na mocy porozumienia sześciu wydziałów Interdyscyplinarne Centrum Studiów Miejskich UŁ we współpracy z Instytutem Historii i Katedrą Socjologii Kultury.

Była to - po wrześniowej konferencji Oddziału Łódzkiego Polskiego Towarzystwa Historycznego - druga w krótkim czasie konferencja zorganizowana przy współudziale Instytutu Historii UŁ, która podejmowała problematykę modernizacji, co świadczy o rosnącym zainteresowaniu tą tematyką wśród badaczy reprezentujących różne dziedziny humanistyki i nauk społecznych oraz odpowiada na ferment intelektualny, jaki wzbudzają wydane w ostatnich latach prace autorstwa Adama Leszczyńskiego, Jana Sowy, Andrzeja Ledera czy Tomasza Kizwaltera, podejmujące próbę reinterpretacji polskiej drogi do nowoczesności. O fermencie tym świadczy także projekt badawczy Cztery dyskursy nowoczesności. Modernizm peryferii na przykładzie Lodzi (XIX-XX wiek), realizowany od trzech lat na Wydziale Ekonomiczno-Socjologicznym przez grono młodych badaczy 